\title{
Marxist and Personalist influences in Paulo Freire's pedagogical anthropology
}

Influencias marxistas y personalistas en la antropología pedagógica de Paulo Freire

\author{
Nicolò Valenzano \\ email: nicolo.valenzano@unito.it \\ Università degli Studi di Torino, Italia
}

\begin{abstract}
Resumen
Paulo Freire estuvo profundamente influenciado por la filosofía marxista y el personalismo de Mounier, tanto en términos de compromiso cívico, tanto por la búsqueda constante de prácticas de emancipación humana, como por algunos aspectos específicos de su pensamiento. En este artículo me concentro en el legado en lo que se refiere a antropología pedagógica. La centralidad de esta pregunta proviene de la idea de que, en Freire, el punto de inserción a los problemas pedagógicos es antropológico. En la segunda y tercera sección me centro en cómo Freire conoció a Marx y profundizo en algunos aspectos para resaltar el vínculo entre los dos autores. En las secciones cuarta y quinta analizo el legado del personalismo latinoamericano en la antropología pedagógica de Freire. En conclusión, sostengo que la originalidad del pensamiento de Freire y su relevancia deben buscarse en la forma en que mezcló estas dos tradiciones.
\end{abstract}

Palabras clave: antropología pedagógica; Paulo Freire; el personalismo de Freire; el marxismo de Freire; filosofía de la educación.

\section{Abstract}

Paulo Freire was profoundly influenced by Marxist philosophy and Mounier's personalism, both in terms of civic engagement, particularly in the constant search for practices of human emancipation, and in specific aspects of his thinking. In this paper, I focus on the legacy of both in Freire's pedagogical anthropology by drawing from the idea that, in Freire's works, the point of entry to pedagogical problems is anthropological. In the second and third sections of the paper, I focus on how Freire met Marx and highlight the link between the two thinkers. In the fourth and fifth sections, I analyse the legacy of Latin American personalism in Freire's pedagogical anthropology. In conclusion, I argue that the originality of Freire's thinking and its relevance stem from how he mixed the two traditions.

Keywords: pedagogical anthropology; Paulo Freire; Freire's personalism; Freire's Marxism; philosophy of education.

Cómo referenciar este artículo / How to reference this article:

Valenzano, N. (2021). Marxist and Personalist Influences in Paulo Freire's Pedagogical Anthropology. Tendencias Pedagógicas, 38, pp. 68-82. doi: 10.15366.tp2021.38.007. 


\section{Introduction}

Paulo Freire was an educator who drew from different disciplines and philosophical traditions to the point that the eclecticism and originality of his thought has become the subject of heated debate (Egerton, 1973; Leach, 1982; Taylor, 1993; Coben, 1998; Roberts, 2000). During his youth, Freire found inspiration in the French tradition of Christian humanism, particularly in the personalism of authors such as Pierre Teilhard de Chardin, Jacques Maritain, and, above all, Emmanuel Mounier. In Freire's works, particularly in his discussions of consciousness, critical reflection, human development, community, and human action, the influence of those three French philosophers is profound. As a humanist with a personalist tradition, Freire espoused the intrinsic value of human beings and was convinced that all people have a so-called «ontological vocation» that motivates them to make the most of themselves and become fully human, not as isolated individuals but in communion with others. Likewise, he identified injustice, exploitation, and oppression as impediments that prevented people from progressing towards full humanisation and therefore constituted a distortion of their ontological vocation (Freire, 1972a). In his involvement with the youth movement Catholic Action, Freire became familiar with the incipient movement of liberation theology, according to which Christians have a moral obligation to reject exploitation (Gadotti, 1994). He was particularly inspired by the ideas, commitment, and pastoral work of Hélder Câmara, known as the Red Bishop due to his struggle for social justice and human rights. While working with workers and peasants, Freire began asking questions about the roots of exploitation and exploring the answers through Marxist theory. He was driven to do so not only by the reality of oppression but also by the religious perspective of the people who understood misery as a test imposed by God. Indeed, in many works since The Pedagogy of the Oppressed, Freire used some of Marxism's analytical tools. Even so, that tendency did not make him abandon his humanist or personalist philosophy: «God led me to the people, and people led me to Marx. [...] But when I met Marx, I continued to meet Christ on the corners of the street-by meeting the people» (Freire, 1974). Although Freire admitted that Marxism and Christianity could be viewed as contradictory frames of reference, he also admitted that he could handle that tension: «I have always spoken to both [Christ and Marx] in a very loving way. See, I feel comfortable in this position. Sometimes people tell me that I am contradictory. My answer is that I have a right to be contradictory, and secondly, I don't consider myself contradictory in this» (Horton, Freire, 1990, p. 247). In sum, it can be argued that in that dialogue between personalist humanism and Marxist humanism, it is possible to find the foundations of Freire's philosophical approach and the fundamental concepts of his political-educational theory.

The tension between Marxism and communitarian personalism is the focus of this paper. I dwell not on how those two currents influenced Freire's thought tout court but only on his pedagogical anthropology, which represents this point of departure and the arrival of the educational proposal. In the second and third sections, I analyse how Freire approached Marxism and focus on how Marxism influenced his conception of anthropology. In the fourth and fifth sections, I examine Freire's associations with Brazilian personalism and describe how the legacy of Mounier's conception of anthropology influenced Freire's ideas.

\section{Marxist influence}

Marxist philosophy influenced Freire both in specific aspects of his thought and in his civil commitment, which he intended to use not only to fight capitalist relationships with production and the condition of oppression but also to study practices of human emancipation. Karl Marx's first writings receive conspicuous reference in Freire's early works and provide the basis for his social analysis, as exemplified in The Pedagogy of the Oppressed (Mayo, 2004). To abstract Freire's ideas from the Marxist theoretical context would be a mistake, one that runs the risk of losing the precision of his analysis and ignoring the transformative intent of his work (Allman, 1999).

It is likely that Freire, as a young man, had little direct knowledge of Marx's texts and was a more attentive reader of the twentieth-century interpretations of the philosopher from Trier offered by Erich Fromm, Paul Sartre, György Lukács, Karel Kosík, and Antonio Gramsci, to name a few (Roberts, 1998; Mayo, 1999; Secci, 2017). One of Freire's first encounters with dialectical materialism occurred via the influence exerted by the humanist positions of Herbert Marcuse and Fromm and can be found especially in his early works. Indeed, from their reading of the Economic-Pbilosophical 
Manuscripts of 1844, both Marcuse and Fromm draw a reduced version of «concrete humanism» which influenced Freire. The analyses of negative reason in industrialised societies and the phenomenon of massification proposed by Marcuse also resonated with Freire, as do Fromm's arguments about reification and psychological freedom, both of which are incorporated by the Brazilian educator, especially in his arguments about democracy as a political context (Torres, 2017).

Without entering into the historiographical debate and pondering whether Freire's Marxism matured starting only in the 1970s, as suggested by John Elias (1994), it nevertheless remains impossible to not notice how Freire's interpretation of Marx is mediated by those (and other) authors hybridised by the Latin American context and by the influence of the philosophy of liberation (Rivera, 2004; Schugurensky, 2011).

If Marxism, as a theory of the emancipation of humankind, has an implicit pedagogical component, then it is articulated in a sociological investigation of the state of education, in a philosophical critique of the problems with human nature and human ends, and in a specific definition of determined pedagogical choices (Manacorda, 2008). Freire's debt to Marx, found in his stances on an array of issues, can be traced in all three of those articulations (McLaren, Farahmandpur, 2002; Mendonça, 2008; Jardilino, 2008; Azevedo, 2010; Malagón Plata, 2010; Krees, Lake, 2013). Consistent with that philosophical tradition, the Brazilian educator's thought underscores the importance of ideology and conscience, of praxis as a dialectical unification of thought and action, of alienation, of dehumanisation as the reduction of people to the status of things, and of liberation via social transformation. In general terms, the dialectic of social conflict that Freire identifies between oppressors and the oppressed is in direct debt to the Marxist interpretation of the theory of dialectical materialism. From a methodological point of view, in proposing a practice of emancipatory education the Brazilian philosopher used historical materialism as a method of social investigation (Mafra, Camacho, 2017).

Another central idea of Marxism that influenced Freire is the concept of false consciousness (Marx, Engels, 1947). Marx argued that members of society's working class have been manipulated by a range of ideological means, primarily through the interaction of the structure and superstructure, to adopt perspectives and values that harm their interests while favouring those of the ruling class and increasing their capacity for control. Freire interpreted education as a functional means for the reproduction of social inequalities; using Louis Althusser's terms, he argued that education and school are components of the superstructure that benefit the rich in various ways, including by instilling the dominant ideology in students (Althusser, 1970). The notion of depositary education, or banking education, undoubtedly derives from the theme of false consciousness, as does Althusser's theory (Freire, 2000).

In this contribution, I leave those Freirean debts in the background in order to focus exclusively on how Marxism influenced Freire's anthropological vision and thus dwell on the «anthropologicalformative» element of pedagogical Marxism (Cambi, 1994, p. 46). Freire's first Marxian readings do not start with an attempt to understand what economic production is, nor to seek in-depth knowledge of the world, but to focus on the idea of humankind (Cleber, 2002). Herein, I seek to show how those Marxist ideas shaped Freire's understanding of human nature and education.

\section{Freire's reading of the Marxist conception of anthropology}

In this paper, I do not venture into the discussion of whether Marx's philosophical anthropology is merely a theme of the youth period or an integral, decisive part of the overall Marxian conception of reality. Instead, I present the ways in which the Marxist interpretation of that anthropological vision influenced Freire and affected his pedagogical reflection.

Marx's conception of anthropology and its subsequent Marxist interpretation, similar to Freire's, takes as its starting point the concrete human person within their social bonds, not the supernatural world and the visions that it conveys. In short, Marx constructs a coherently anthropocentric anthropology without supernatural references. Conversely, a vision that starts from a superhuman world or a god would conceive humankind as an end point and therefore assume its heteronomous character (Schaff, 1970).

Both Freirean and Marxist perspectives can be interpreted as forms of humanism (Davies, 2008). Marxism is humanism, according to the interpretation of some Marxists such as Althusser, Lukács, and Karl Korsch, because it is a system of reflection on humankind that, in recognising the supreme 
good in people, tends to put in place the best conditions for achieving happiness (Schaff, 1970). The ultimate goal of Freire's reflection is the liberation of every single person from the conditions of oppression - that is, the material and mental conditions that generate subordination and thus unhappiness. Indeed, all of Freire's theoretical elaborations and educational practices are forms of eudaemonism.

Therefore, in this section, I focus on some conceptual nuclei that can be regarded as Freire's obvious debts to Marxism. In particular, I examine the material and corporeal dimension of humankind, its historicity and the concept of praxis, human emancipation, and relationality as a constitutive dimension of humankind.

\subsection{Natural beings: The materiality and corporeality of bumankind}

For Marx, a person is, above all, a natural, objective, material being: a «being in the world», as Freire would say in more existentialist terms. The rejection of Hegelian philosophical theology leads to Marx's careful reflection and re-evaluation of the corporeity, naturalness, and physicality of humankind. Such attention paid to the body, which ranks among the most distinctive features of Marx's philosophical anthropology, is recovered by Freire, who integrated it with a phenomenological, existentialist influence. The revaluation of the body is connected to the revaluation of work as a central element of the entire Marxian theoretical framework, one that should be contextualised within the idea of praxis (Marx, 1961; Marx, Engels, 1947).

That revaluation first entails a rejection of any conception of a negative dimension of the human in the body and, vice versa, a re-evaluation of the body's needs as belonging to the domain of the essence of humankind. Second, it reveals the fundamental situation and fragility of human condition. The Freirean notion of corpo consciente ('conscious body'), from that perspective, fits well with the notion of incompleteness from which human frailty can derive (Gonçalves, 2010). The body is therefore seen as constitutive of the person: as a defining trait and not a mere accident that adds to or supports the conscience, conceived as the seat of individual identity. It is also interpreted, following Merleau-Ponty's teaching, as something perpetually situated. That vision of the body provides the theoretical basis for Freire's reflections on the body of the human in exile (Freire, Faundez, 1985; Freire, 2000).

\subsection{A being of the species: Humankind's historicity and praxis}

Because the concept of the natural being cannot encompass the complexity of the human condition, Marx identifies the particularity of human nature in the concept of Gattungswesen ('being that belongs to a species' or 'generic being'): «man is not merely a natural being; he is a human natural being. That is to say, he is a being for himself, and therefore a being who belongs to a species» (Marx, 1961, p. 174). Humanity is, therefore, the characteristic that ennobles the naturalness of humankind. The concept of Gattungswesen indicates not only the entity belonging to a natural species but more specifically the constitutive relationship that the individual person has with society, history, and all of humankind. The concept of Gattungswesen is indeed conceived by Marx in immediate relation with the theme of humankind's historicity and, therefore, of praxis (Marx, Engels, 1947). It is precisely that meaning of Gattungswesen that Freire contemplates and develops in his anthropological reflections, in which he rejects the abstract idea of human nature derived from Feuerbachian thought.

The human being as a historical being is the basis of all critical philosophy, including that of Marx and Freire. From that perspective, critical inquiry is possible only through a dual historicity: the historical recognition of a person and the historical recognition of people who have questioned that person. That double historicity also fulfils the need to situate reflections on humankind in concrete human reality, not in metaphysical speculation.

Freire's reading of significant authors in the study of the philosophy of praxis, including Kosík, Gramsci, and Adolfo Sánchez Vázquez, contributed substantially to the theoretical elaboration and delineation of his idea of man and to the construction of its educational proposal. In the preface to the Mexican edition of the Dialectic of the Concrete, Sánchez Vázquez writes that the movement for societal renewal, starting with Kosík, developed on a dual basis: first, with a return to Marx, once stripped of the myths, schematism, and limitations to which he had been subjected for years by a dogmatic conception of Marxism; and second, with the analysis of new ideas and realities that Marx 
could not know but that cannot be ignored by an active, creative form of Marxism (Sánchez Vázquez, 1967). Kosík's reading of Marx's texts and use of his concept of praxis were crucial to the development of Freire's critical eye with respect to education, and the Kosíkian position against the indoctrination and manipulation of the masses by leaders would manifest in the Brazilian educator's analysis of teacher-student relationships. Studying Sánchez Vázquez's Filosofía de la praxis afforded Freire a more profound intellectual relationship with the philosophical foundations of the concept of praxis deriving from Hegel, Feuerbach, Marx, and Lenin (Sánchez Vázquez, 1967b; Carvalho, Pio, 2017). It also allowed him to explain the concept of practice in light of the unitary relationship between theory and practice that characterises its constitution.

To answer the question «What is humankind?», Marx contemplates the idea that praxis is its definitive trait: the ability to transform objective reality and, in turn, oneself, because changing the conditions of personal existence has the result of changing and creating oneself (Schaff, 1970). The transformative potential of humankind, conceived as a determining trait, is also a central element in Freire's pedagogy of liberation, especially his elaboration of human emancipation, humanisation, and ser mais («to be more») on a fundamental anthropological fact: praxis as a person's ability to transform themselves and the world. Owing to that interpretation of the Marxist concept of praxis, Freire avoids one of the «fundamental aporias of Maxrist pedagogy»: that the unity of culture and production is a consequence of a limiting interpretation of the concept of work (Cambi, 1994, p. 19).

Despite those broad similarities, Freire's notion of praxis diverges significantly from the Marxist one. For one, Freirean praxis is not coupled with work that the German philosopher applied as the ontological basis of humanity. Second, Freire's conception is dialogic and not individualistic; praxis is a relationship between subjects, not between subjects and objects. Third, in educational and social relationships, Freire "gives priority to communicative dimensions and love rather than conflict» (Morrow, Torres, 2002, p. 28). By involving the oppressed in their own processes of learning, critical pedagogy becomes both a philosophy and practice of reflective action among all people, not only workers, and is informed by the goals of Marxism and has the potential to advance them. Nonetheless, Freire's humanistic praxis retains value in the concrete context, in local struggles, and in social movements in which individuals «must articulate particular utopian visions within their own unique life stories» (Morrow, Torres, 2002, p. 29). Thus, in Marx as in Freire, the possibility of transforming praxis exists precisely in the dialectic between the singularity and concreteness of every person's life and the general and abstract dimension of the utopian visions that spur action.

Another decisive point of divergence between Freire and the philosopher from Trier can be traced to the role of consciousness in transforming praxis. While both thinkers viewed the aim of history as liberation from oppression, Marx nevertheless emphasised the social structure, while the Brazilian philosopher underscored the importance of the dimension of individual conscience. In the latter case, change as a social transformation can occur only via the reflection, recognition, and action of the oppressed to free themselves from the conditions of oppression (Dale, Hyslop-Margison, 2010). In the 1970s, that position, in which existentialist and personalist influences are evident, was submitted to various criticisms by Marxist authors that Freire responded to in the Pedagogy of Hope. In his opinion, the denial of subjectivity in the analysis of reality, in the theory of action, and in transforming praxis involves a form of objectivism, just as the denial of objectivity leads to subjectivism and solipsistic positions: «Subjectivism or mechanistic objectivism, both antidialectic, unable, therefore, to understand the permanent tension between consciousness and the world» (Freire, 2014, p. 106). From Freire's point of view, a correct interpretation of Marx implies the recognition that what the philosopher from Trier «scientifically criticized and destroyed was not subjectivity, but subjectivism, psychologism» (Freire, 2000, p. 47; Jorge, 1979). The need to understand subjectivity and objectivity in their dialectical unity - that is, as interdependent dimensions to be developed-represents a way to discover forms of praxis and thereby make overcoming mere activism and simple intellectualism possible.

\subsection{Human Emancipation}

In The Jewish Question, Marx endeavours to seek the philosophical basis of human and political emancipation. With respect to that theme, he posits that all human beings must take responsibility for their existence, namely by transforming tradition and historical heritage into resources that can 
be used to undertake a new or renewed liberating practice. Leaving aside the reconstruction of Marx's criticism of Bauer, what interests me here is that human emancipation is one of the most important legacies of pedagogical Marxism (Mata, 2016), one that involves the problematisation of the processes of constituting one's existence and, from there, a critique of contexts, moments, and one's hegemonic historical beliefs. From that standpoint, emancipating oneself is equivalent to the deconstruction and reconstruction of the existential conditions that make one's way of being in the world possible. Therefore, for Marx as for Freire, before becoming able to emancipate others, every person has to first begin to emancipate themselves (Marx, 1975). Emancipation therefore needs to be understood both as existential self-criticism, which allows the criticism and transformation of situations of oppression, and as the removal of the oppressor present in every oppressed person. As shown earlier, Freire retrieves that Marxian instance with reference to Fromm's interpretation of the notion of fear of freedom (Fromm, 1995; Lake, Dagostino, 2013).

The parallelism between Marx and Freire on that point rests on the idea of a human being who, questioning themselves, also questions the world, and in transforming themselves, transforms the world. In that light, the Brazilian philosopher's theory on transforming praxis is a consequence of a specific anthropological vision strongly influenced by Marxist positions.

\subsection{A social being}

In the preceding pages, Freire's anthropological-philosophical principles have been read through the interpretative lens of Marx, according to which human beings are affirmed to be historical beings following two rationales. On the one hand, history shapes humans, influences the way that they face daily life, and interacts with the world conditioning all forms of life. On the other, human beings are historical beings because they are part of history, immersed in it, and continually determine it via their actions. By becoming aware of their own historicity and fully understanding the bidirectionality in which that feature operates upon reality, human beings materialise the real possibility of being authentically free. Only by becoming aware that they are the builders of their own history can human beings understand freedom. They do so always in relation with others, for that freedom, according to Freire, is possible only in relationships with others.

If people are the products and at once the architects of history and society, then for Marx they can be conceived as social individuals. From that position, he does not simply repeat the Aristotelian assertion that a person is a zôon politikòn but argues that people are products of society and that their present essence is also a product of society. In those terms, the well-known sixth thesis on Feuerbach has to be interpreted, according to which human essence «is no abstraction inherent in each single individual. In its reality it is the ensemble of social relations» (Marx, 1978, p. 145).

When Marx argues that «the individual is a social being», he intends to focus on the problem of the essence of a person as one that is inextricably connected to relations with others (Marx, 1961, p. 114). Along those lines, Marxian philosophical anthropology is relational, not only in the Feuerbachian sense of I-you relationships but also, and more significantly, in the network of social relationships that define the human community. For Marx, zôon politikòn means that a person «is not only a social animal, but an animal that can isolate itself only within society» (Marx, 1971, p. 10), an idea from which emerges their constitutive sociability.

Arguably, Marxist anthropology is a philosophical anthropology of a social character for two reasons: one, because sociality is a constitutive characteristic of the individual as a social being, and two, because it is in and through social relations that individuals can seek personal happiness and the satisfaction of achieving personal goals. In Marx, the original anthropological question, which cannot be eluded by any philosophical reflection on humankind-that is, the conditions of individual happiness-finds a solution in the social domain (Schaff, 1970). From that point, it is possible to trace Freire's debt to Marx: the description of humans as beings who need others to ser mais ('to be more'), in clear distinction from all forms of individualist anthropology. Those Freirean positions run through all of his works but are particularly evident in the first two chapters of The Pedagogy of the Oppressed, in the exposition of his pedagogical and political ideas in terms of liberation and educational processes. For Freire, understanding the foundation of relational anthropology requires deepening the connection between the historical being and the relational being. Humans are relational beings in social contexts; therefore, they are historical beings embodied in the history and civilisation of different peoples. Understanding humans as relational beings allows recognising the history of the 
human species and the biography of each individual as a process of humanisation in which everyone, in their relationships, makes the connection between the historical and the relational possible and can prompt social transformation. For Freire, humanisation is therefore not a process of adaptation in which people naturalise themselves but instead an activity through which they humanise the world. In that sense, humanisation is not only a biological process but also a historical one (Fiori, 1970). If the chief factor of humanisation is education, then it can be inferred that education should not be conceived in a functionalist light, namely as an adaptation to the world, but more significantly as an activity of the humanisation of the world, one that allows people to cultivate the qualities to transform the world.

Perhaps the most precise point of juncture between the idea of the human being as a historical being and as a relational being is dialogue understood as a particular articulation of sociality and placed at the foundation of all Freirean relational anthropology. Historical beings recognise themselves as a collective, for they establish a dialogue with others insofar as they claim others as historical beings and, with them, seek to conquer the historical vocation «to be more». In the relational anthropology of Marx and Freire, human beings are characterised as beings open to realising themselves in their relations with the world and with others. The illumination of the human condition requires an inexorable encounter with the unknown represented by the other and the other's existence, as well as the need to establish dialogic, horizontal relations of recognition of the other. Only in that way can human beings exit themselves and transform their existence beyond the simple satisfaction of material needs. That exiting of the self to meet the other is interpreted by Freire as transitivity, as a characteristic of transitive consciousness, and as a kind of openness and relationship with another. In those terms, transitive consciousness: makes man permeable, and it leads him to overcome his lack of commitment to existence, which is characteristic of semi-intransitive consciousness, to the point of becoming almost totally committed. Precisely for this reason existence is a dynamic concept, which implies an eternal dialogue between man and man, man with the world, man with his Creator. (Freire, 2005, p. 15)

It is precisely the dialogue of a person about and with the world that makes them a historical subject in the dual sense indicated: a being conditioned by history and by society and a being who creates and transforms history and builds culture.

Freire's relational anthropological proposal is therefore configured through an exchange with Marx and is specified in its philosophical-anthropological and anthropological-pedagogical aspects. As for the first aspect, relational anthropology is based on the encounter with the other as the basis of the human condition to need to establish social bonds. For Freire, human beings are relational beings that exit themselves during encounters with others. The other is thus fundamental in Freirean philosophy and pedagogy, and a humanising dialogue can be established thanks to its presence. As for the second aspect, the anthropological-pedagogical one, the affirmation of relational anthropology is critical to understanding Freirean liberation pedagogy, which supports the need for the oppressed to try to transform themselves and transform the world through dialogue.

\section{The influence of Latin American personalism}

In the period following World War II, personalism enjoyed broad diffusion in Latin America, where it became crossed and shaped by the ideas of other thinkers and ultimately gave rise to an original synthesis. It also served as a conceptual tool for many Brazilian intellectuals, including Freire, to analyse the national situation. In general terms, personalism emerged in Latin America as a movement, one most prominently advocated by Mounier, with the aim of promoting society's renewal and meeting the aspirations of the young people of the era (Ruedell, 1985).

Because Freire was so strongly influenced by personalism as a movement and by Mounier's thought in particular, it is appropriate to first advance some clarifications before proceeding with the discussion (Chagas, Rocha, 2013; Klenk, 2014; Kirylo, Boyd, 2017; Leopando, 2017). Although those influences are most evident in Freire's early works, later, starting in The Pedagogy of the Oppressed, he began to use Marxist categories such as that of «class struggle». The personalist and Christian theoretical matrix, however, had not lost importance in his ideas; if anything, it had waned in influence just as new theoretical references emerged between the second half of the 1960s and the 1980s (Scocuglia, 1998; Gerhardt, 1996). 
Freire's knowledge of Mounier's thought seems to be more influenced by indirect readings and encounters mediated by other intellectuals than by direct knowledge of the French philosopher's texts, which were nevertheless not lacking among his readings. In Brazil, the primary mediator of French personalism, particularly the work of Mounier and Maritain, was Alceu Amoroso Lima, a journalist, cultural critic, and activist, as well as the national president of the Ação Católica Brasileira from 1935 to 1945. Also known by the pseudonym of Tristão de Ataíde, Lima wrote a popular Sunday column in the Jornal do Brasil and directed the Dom Vital Center, a small but highly influential Catholic institute amongst intellectual elites, including Freire and his friend Hélder Câmara (Skalinski Junior, 2015). The good fortune of French personalism and of Mounier is also attributable to the work of two Brazilian Jesuits, Almeri Bezerra and Henrique Cláudio de Lima Vaz, who were involved with the student movement and deeply influenced by the philosophies of Maritain, Mounier, and Teilhard de Chardin. In 1959, Bezerra had delivered a presentation at the annual conference of the Juventude Universitária Católica (JUC) in which he proposed the thesis that Catholic activism should be guided by a synthesis of putatively eternal theological truths and the putatively scientific analysis of concrete historical conditions. The philosophical basis provided by Bezerra was elaborated by Lima Vaz at the 1960 JUC conference. Similar to his Jesuit companion, Lima Vaz was concerned with the philosophical and theological foundations of modern change and affirmed the Christian responsibility to shape history. Thus, whereas Bezerra was heavily influenced by Maritain, Lima Vaz was heavily influenced by Mounier (De Kadt, 1970).

Gerhardt's description of the relationship between Freire and the radical Catholic youth movement, as well as the similar role that he played in the national historical moment of the 1950s and 1960s, suggests how their affinity was based on a common reference to the personalist tradition, primarily the French tradition, and its Brazilian interpretation (Gerhardt, 1996). The JUC groups often engaged in the discussions of leading French Catholic thinkers, and Mounier's philosophy was particularly popular with young activists (Holbrook, 2013). Freire was influenced by the younger generation of the Juventude Escolar Católica and the JUC, who passed from Maritainism to Mounierian personalism, although he later criticised the former. Freire was more aligned with the young people who referred to Mounier, who refused to concentrate on developing strategies to seize political power, who viewed groups engaged in that task (massificadores) with distrust, and who instead stressed the importance of long-term educational work (Paiva, 1980). For the militants of the JUC first and of the Ação Popular later, Freire's language was familiar and reliable, and his proposals were interpreted, in one way or another, as the proposals of Christianity tout court (Beisiegel, 1989). Mounier also exerted a powerful intellectual influence on the Popular Culture Movement, in which Freire was the main educator (Coelho, 2002).

\section{Freire's reading of Mounierian conception of anthropology}

French personalism thus exerted decisive influences on Brazil's progressive Catholic elites during the period in which Freire reached maturity as an educator, activist, and thinker. The interest in humanisation, which spanned the entire life and reflection of the Brazilian educator, is deeply influenced by personalist authors, including Maritain, Mounier, and Teilhard de Chardin. In the following pages, I examine themes that derive from French personalism and Mounier's influence on Freire's conception of anthropology. In particular, I focus on a consequence of the centrality of the human being, the notion of embodied existence, humankind as being in communion, and the ontological vocation of ser mas («to be more»).

\subsection{The centrality of the person}

The central affirmation of personalism is the existence of free, creative people. The concept of the person can be approximated by distinguishing it from that of the individual, namely by the «spread of the person to the surface of his life and his willingness to lose himself in it». The individual is therefore marked by dispersion, selfishness, capricious aggression, and «the dissolution of the person into matter» (Mounier, 1935, p. 48). Mounier criticises individualism for proposing a vision of freedom that is too insular and unable to understand the needs to give of oneself and to collaborate, which are inherent in human beings and intrinsic to their freedom. The conviction according to which each person is not objectified, that they cannot be reduced to things, represents an anthropological 
premise of Freire's pedagogical reflection under the influence of Mounier. Starting from that premise, in the work of the Brazilian educator, two consequences can be traced to the social level: the critique of welfarism and the critique of dehumanising capitalism.

In his critical presentation of the Brazilian context in Educação e atualidade brasileira, Freire highlights a source of antinomy, one that runs through the text, between democratic inexperience and the emergence of the people in public life. From there, he approaches the concepts of welfarism, populism, and mass production that influence the levels of consciousness of individuals (Freire, 1959). A close reading reveals a distinct example of personalism's influence, namely when the author criticises assistencialização, or 'assistentialisation'. Freire interprets welfare as an undemocratic strategy of the social structure because, unlike conscientisation, it preserves people's silence and immobility. A similar criticism has been levelled against assistance by Brazilian progressive Catholics (Beisiegel, 1989). In both cases, it is possible to see in Mounier's thought the source of those critical positions, particularly in his concept of prise de conscience (Mounier, 1936, 1946). The second theoretical consequence that Freire assimilated from Mounier consists in the critique of individualist capitalism that denies human dignity. Cast in that light, Freire's reading of conscientisation is fundamentally based on a critique of capitalism and its production of symbolic as well as political alienation and exclusion, which echoes the Marxist orientations mentioned in the previous section.

Despite the difficulty of defining the concept of the person, Mounier proposed identifying three constitutive dimensions: vocation, incarnation, and communion (Mounier, 1935). In the following three paragraphs, I analyse those three aspects, reveal their consequences, and highlight how, along with being distinct traits of community personalism, they are also characteristics of Freire's conceptions of anthropology and the pedagogical proposal.

\subsection{Embodied existence and integral humanism}

Mounier rejects the ancient theological dualism between body and spirit. Instead, he conceives people as being formed entirely of body and spirit, because they perform actions for their own survival and are at once endowed with spirit (Mounier, 1949). As a body, a person is a natural being; therefore, nature is not to be considered in an exclusively negative way or as the evil of the spirit: «Incarnation is not a fall» (Mounier, 1949, p. 19). By extension, Freire repeatedly insists on the relevance of corporeality within his own theoretical framework, especially by characterising humankind as a conscious body, both in anthropological-philosophical terms and on anthropological-pedagogical premises, as well as in concrete educational practices.

From that instance of unity between body and spirit follows the reference to the totality of the person. By affirming the «total man», the thought of Mounier and Maritain rejects all political, economic, philosophical, and theological systems that deny the spiritual dimension of human existence, primarily bourgeois capitalism and totalitarian collectivism. In particular, Maritain argued for what he called «integral humanism», because a humanism that leaves the spiritual dimension outside the definition of what it means human being is a partial humanism (Maritain, 1936). Consistent with that approach, education has to be holistic in Freire's thinking, for it engages human formation and cultivates moral intelligence (Freire, 2001). Reflecting on Maritain, Freire affirms that the education of workers should not leave them «deprived of critical sense and capacity for judgment in the face of problems outside their specialization» but should instead harmonise a humanistic, technology-oriented position to facilitate genuine cultural and political democratisation (Freire, 2005, p. 74).

\subsection{Being of communion: dialogue and community}

Dialogue and the reference to the human being as constitutively relational are also anthropological categories used by both Mounier and Freire. Communication, the term preferred by the French personalist, along with dialogue and relationship constitute the fundamental experience of the person: «Contrary to a current opinion, this experience is not originality, disdain, affirmation solitary, it is not detachment: it is communication» (Mounier, 1949, p. 33). As such, communication establishes an interpersonal relationship that is «a mutual provocation, a reciprocal fecundation» (Mounier, 1949, p. 41). 
Unlike individualism, which is essentially a philosophy of isolation and self-absorption, personalism's central concept bears witness to the constant dynamic of moving outside the self to provide an opening for challenges that make human beings struggle and, in turn, work towards a «humanized» humanity (Mounier, 1949). Starting from the same conception of communication's centrality to existence, Freire created a method of literacy that uses the routine activities of students to promote social inclusion and their liberation. The method uses dialogue as a pedagogical attitude and communication as a learning tool and, at the same time, promotes literacy, education, and political awareness.

Altogether, Freire's theory of dialogic action shows some characteristics that bring it closer to Mounier's theoretical elaboration, especially the centrality of the concept of collaboration. Therein, subjects, through practices of love and communication, enter in communion and become capable of collaborating towards achieving the transformation of the world. Other shared characteristics include the notion of the union among the oppressed towards liberation and of revolutionary leadership with the masses; the theme of the organisation of the masses to struggle, to learn how to name the world, and to indeed name things; and cultural synthesis, whereby protagonists unite with the community, which thus becomes an actor in the action. In personalism, the person is therefore a direct presence for others and in the world, and, in that sense, Mounier's personalism is communitarian. In opposition to individualism and idealism, the French philosopher believes that «the subject does not feed on self-digestion», for «one possesses only what we give or what we give ourselves» and, as a result, «we cannot save ourselves, neither socially nor spiritually» (Mounier, 1949, p. 35). From that perspective, a person needs the community to communicate and, in that way, realise them as persons. Freire, similar to Mounier, was concerned with building a community of people. To that end, he conceived education as a service for the demassification of humankind and for its liberation from pettybourgeois individualist culture. That conception of education is personalist, because it does not entail the acquisition of a wealth of information and/or skills, not even in the preparation or execution of a professional social function, but in the awakening of the person (Lorenzon, 1996). From that standpoint, educational institutions should be community centres that educate students and families «in the sense of social and political responsibility» (Freire, 1959, p. 96).

\subsection{The human vocation: Transcendence, incompleteness, and research}

If a person, as an embodied existence, is a natural being, then they are nevertheless endowed with the capacity to transcend that condition. Thanks to people's creative (and transformative) activities, they emerge from nature by personalising it— that is, humanising it (Mounier, 1949). In that light, a person «is not content with being subjected to nature, from which it emerges, and reacting to its stimuli: he also turns towards it to transform it and impose on it more and more the dominion of the personal universe» (Mounier, 1949, p. 27). Productive activity is essential to the human person, although production assumes value and meaning only in relation to its lofty purpose to create a world of people while contrasting the underlying depersonalising tendency. Considering the interdependence between humankind and the world in Mounier's thought, Freire (2005) considers people as beings of integration when they assume that their role is that of subjects of action-that is, when they begin to think and act by integrating themselves into their socio-economic and cultural contexts. As beings of integration, not accommodation, people represent an anthropological category that the Brazilian philosopher derives from his interpretations of Mounier's thought. From the personalist perspective, the process of humanisation is a continuous movement that allows a person to be fulfilled by way of their own overcoming: «Man cannot be satisfied with rest in well-being: he aspires to au plus-être» (Devaux, 1965, p. 4). Such thinking is particularly evident in Freire's fundamental conviction, according to which all people can and should face the challenge of becoming «more fully human», namely by becoming aware of their historical condition and taking responsibility for creating a more just world. That basic assumption imbues the initial lines of The Pedagogy of the Oppressed, in which Freire declares that the struggle for humanisation has always been the central problem of humankind (Freire, 2000). In the same work, Freire also argues that «banking» educational practices are inherently immoral because they deprive learners of their «ontological and historical vocation» to become more human (Freire, 2000, p. 55).

As a result, the notion of overcoming, which in Freire's thought is incorporated as transcendence, assumes centrality in the conception of anthropology and consequently affects XXX at the cognitive 
and behavioural levels. The aim of education, from that perspective, is not the construction of oneself as a means of self-improvement, but the construction of an open, constitutively relational subject capable of taking care of the others. Human incompleteness establishes the educability of the person in the direction of relational subjectivation and is thus an incompleteness that, instead of inducing the search for perfection, invites an encounter with the others. Each person is conceived as a being in search of themselves, in the sense that they are never finished, nor is it possible to define them once and for all, for they are being made to overcome themselves and to always venture beyond what they are. In that regard, Jean Lacroix wrote, «The person is less a given than an achievement, it lives a continuous creation [...] The person is not all complete, but it is becoming, it is to be done» (Lacroix, 1981, p. 38).

That ability to transcend the self, to become more fully human by way of ceaseless study, transformative praxis, and relationships with others, all of which characterises humans as beings that emerge from nature, constitutes the anthropological basis upon which Freire proposes frequent comparisons between human and animal existence. Those insistent references to the diversity and exceptionality of human beings show the Brazilian educator's debt to French personalism. According to Freire, only humans have the ability to enter «into domain is which is exclusively theirs- that of History and of Culture» (Freire, 2005, p. 4). Humans are the only creatures that exist rather than survive. They have the potential to transcend «mere being in the world» via conscious acts of transformation, production, decision, creation, and communication (Freire, 1970, p. 466). Animals, which are unable to venture beyond their biological conditioning, merely adapt to the world. Having no sense of the historical process, they are confined to an eternal present. Those purely instinctive ways of inhabiting the physical world are characteristic of the animal sphere and symptomatic of the dehumanisation practised by humans (Freire, 2005, 2014).

\section{Conclusion: Originality beyond the contradiction}

In Freire's conversation with Myles Horton in which he defended his right to be contradictory, Freire stated that he did not see any irreconcilability between his Catholic faith and his Marxist ideology because he considered those approaches to be complementary (Horton, Freire, 1990). A consensus exists among scholars that Freire's approach was eclectic. However, the term eclecticism can be used in either a derogatory or a positive sense. Whereas some attribute a negative connotation to the term, implying efforts often create internal inconsistency and fruitless results, others prefer the term interdisciplinarity and argue that crossing the boundaries between academic fields and schools of thought, along with the careful selection of theories, can integrate and combine ideas in novel ways, illuminate a particular problem, and ultimately produce a new, useful synthesis. The question that remains open is to what extent Freire borrowed, chaotically and in an arguably contradictory way, and was able to develop an original formulation of the different elements that can be considered something other than the sum of their parts. Gadotti, for example, argued that Freire was able to integrate the central elements of the different currents of thought without repeating them mechanically, while Franco observed that, reading Freire, one gets the impression of hearing familiar sounds as well as experiments with a new general harmony (Gadotti, 2001; Franco, 1973). More recently, Dale and Hyslop-Margison have argued that the beauty and collective integrity of Freire's philosophical synthesis prevail over its potential dissonance (Dale, Hyslop-Margison, 2010).

The eclecticism described is not incompatible with the originality of Freirean thought. In that regard, I distinguish two areas of originality: one related to educational practices, the other concerning the theoretical dimension. Those two areas are not simply juxtaposed, for Freire's ventures into different disciplines - philosophy, social theory, political theory, linguistics, and anthropology, as well as possibly psychoanalysis, communication theory, and history-were always guided by his interests in education. That effort to synthesise and reorient different philosophical traditions in the direction of a complete pedagogical elaboration and an innovative educational practice is a trait of his originality that cannot be ignored.

Beyond that, one of Freire's greatest merits can also be understood in terms of the originality of his contributions. The fundamental nucleus of Freirean thought, where the reflection of the Brazilian thinker begins, is located at the crossroads of philosophical anthropology, pedagogy, and politics (Freire, 2014). 
The connection of pedagogy and politics finds its sources in a specific conception of anthropology, comprising the pedagogical thesis, according to which education cannot be neutral but has an active political content, and the political thesis, according to which human praxis has to be oriented towards generating forms of popular organisation to accompany the development of a critical conscience aimed at social transformation. Both theses descend from a precise idea of man. Freire's anthropological-philosophical perspective acquires certain relevance if interpreted as the foundation and interpretative vertex of his pedagogical theory (Leach, 1982; Egerton, 1973; Preiswerk, 1995; Schugurensky, 2011). The Marxist tradition and Mounier's thought, used as sources of his anthropological proposal, are functional to the understanding of the person as an educable subject, of the social context of education, and of the process through which it is realised (Elias, 1994). At the heart of Freire's proposal is therefore the distinct idea of an educable human being and the synthesis of an anthropological-philosophical vision, of a clear political perspective, and of a complete pedagogical reflection.

The connection between the idea of humankind and the educational proposal can be recognised on two levels. On one level, the forms of education have to be adequate for the ends pursued, and indeed, pedagogical anthropology outlines the idea of humanity as being pursued and addresses the purposes of education (Freire, 1972b; Dale, Hyslop-Margison, 2010). On the other, to be valid, educational actions have to be preceded by a reflection on humankind in order to avoid the risk of «adopting educational methods and ways of acting that reduce man to the condition of an object» (Freire, 1972b, p. 49). In that context, the conception of anthropology plays a role as a regulating ideal of educational practices, insofar as the idea of humankind represents the term by which the validity of individual educational actions is judged.

Exemplifying Freire's reasoning, some educational proposals chiefly concern the content to be taught, with pupils conceived as the recipients of that content. The foundation of those theories is a pedagogical anthropology that sees man as a finite being. From that perspective, humankind and the world are given, not built, and the only possibility is to adapt. However, other pedagogical theories place pupils at the centre of the educational project, where they can better grasp the dynamics of the world, build their own vision of the world, and, in that process, become autonomous. Those theories conceive people as incomplete, historical, relational beings, which is a central element of the theoretical and practical efforts that Freire launched in different parts of the world over the course of his life.

Most of today's pedagogical reflection, educational policies, and educational practices seem to have lost that strong anthropological reference, however. In the debate on education, the idea of the neoliberal person, of bomo oeconomicus, centred on the ideology of merit, human capital, competence, and test-based evaluation, is uncritically presumed. Even so, a recent return to reflection on the foundational anthropological dimension, largely in reaction to a functionalist tendency, has redirected the discussion to increasingly technical aspects and diffused technicalities in the pedagogical language that have eroded the space of general, fundamental pedagogical reflection. Reflection on the foundations of the discipline and meaning of education is opposed to that tendency and characterises the current debate, with a bent towards the so-called «learnification» of the more comprehensive educational dimension (Biesta, 2006, 2010). Even the most current issues in education-for example, the use of information and communication technologies in the classroom, the debate on competence, and the possibility of regenerating social bonds as an educational goal-even implicitly refer to the idea of humankind. Every educational action can be enlightened and motivated by pedagogical reflection that assumes specific conceptions of human beings in its framework. In particular, it assumes a definition of the person as a «being to be educated», which is more properly the object of pedagogical anthropology. Recovering the Freirean reflection thus serves to contribute to that trend by placing the anthropological question at the centre of the pedagogical discussion.

\section{References}

Althusser, L. (1970). Idéologie et appareils idéologiques d'état. La pensée, 151, pp. 3-38.

Azevedo de, J. A. (2010). Fundamentos filosóficos da pedagogia de Paulo Freire. Akrópolis - Revista de Ciências Humanas da UNIPAR, 18(1), pp. 37-47. doi: https://doi.org/10.25110/akrópolis.v18i1.3115

Beisiegel, C. d. R. (1989). Politica e educação popular. São Paulo: Ática. 
Biesta, G. J. J. (2006). Beyond Learning. Democratic Education for Human Future. Boulder-London: Paradigm Publishers.

Biesta, G. J. J. (2010). Good Education in an Age of Measurement. Boulder-London: Paradigm Publishers.

Cambi, F. (1994). Libertà da... L'eredità del marxismo pedagogico. Firenze: La Nuova Italia.

Carvalho de, S. M. G., \& Pio, P. M. (2017). A categoria da práxis em Pedagogia do Oprimido: sentidos e implicações para a educação libertadora. Revista Brasileira de Estudos Pedagógicos, 249(98), pp. 428445. doi: https://doi.org/10.24109/2176-6681.rbep.98i249.2729

Chagas, A. M., \& Rocha, A. G. V. (2013). A crítica de Emmanuel Mounier ao problema do homem singular no marxismo. Griot-Revista de Filosofia, 7(1), pp. 26-37. doi: 10.31977/grirfi.v7i1.553.

Cleber, J. (2002). Revisión de las referencias teórico-prácticas del pensamiento de Paulo Freire. In C. C. Saul (ed.), Paulo Freire y la formación de educadores: múltiples miradas (pp. 23-32). Buenos Aires: Siglo Veintiuno Editores.

Coben, D. (1998). Radical Heroes: Gramsci, Freire, and the Politics of Adult Education. New York: Garland.

Coelho, G. (2002). Paulo Freire e o movimento de cultura popular. In P. Rosas (org.), Paulo Freire: educação e transformação social (pp. 31-95), Recife: Editora Universitária da UFPE.

Dale, J., \& Hyslop-Margison, E. J. (2010). Paulo Freire: Teaching for freedom and transformation: The philosophical influences on the work of Paulo Freire. New York: Springer. doi: 10.1007/978-90-481-91000.

Davies, T. (2008). Humanism. New York: Routledge. doi: 10.4324/9780203932568.

De Kadt, E. J. (1970). Catholic Radicals in Brazil. London: Oxford University Press.

Devaux, A. (1965). Emmanuel Mounier, homme de foi, de pensée et d'action. Cabiers de Neuilly, Avril 1965, pp. 3-10.

Egerton, J. (1973). Searching for Freire. Saturday Review of Education, 1(3), pp. 32-35.

Elias, J. L. (1994). Paulo Freire. Pedagogue of Liberation. Malabar: Krieger Publishing Company.

Fiori, E. M. (1970). Aprender a dizer la sua palavra. In P. Freire, Pedagogia do oprimido (pp. 5-11), Rio de Janeiro: Paz e Terra.

Franco, F. (1973). El hombre: construcción progresiva. La tarea educativa de Paulo Freire. Madrid: Marsiega.

Freire, P. (1959). Educação e atualidade brasileira. Recife: Universidade Federal do Recife.

Freire, P. (1970). Cultural Action and Conscientization. Harvard Educational Review, 40, 452-477. doi: 10.17763/haer.40.3.h76250x720j43175.

Freire, P. (1972a). A letter to a theology student. Catholic Mind, 70(1265), pp. 6-8.

Freire, P. (1972b). El mensaje de Paulo Freire. Teoría y práctica de la liberación. Madrid: Marsiega.

Freire, P. (1974). When I met Marx I continued to meet Christ on the corner of the street. Interview with Barry Hill. The Age Newspaper, Melbourne, April 23.

Freire, P. (2000). Pedagogy of Oppressed. London: Bloomsbury.

Freire, P. (2001). Pedagogy of Freedom: Ethics, Democracy, and Civic Courage. Lanham: Rowman \& Littlefield.

Freire, P. (2005). Education for Critical Consciousness. London: Continuum.

Freire, P. (2014). Pedagogy of Hope: Reliving Pedagogy of the Oppressed. London: Bloomsbury.

Freire, P., \& Faundez, A. (1985). Por una pedagogía de la pregunta. Crítica a una educación basada en respuestas a preguntas inexistentes. Buenos Aires: Siglo Veintiuno Editores.

Fromm, E. (1995). The Fear of Freedom. London: Routledge.

Gadotti, M. (1994). Reading Paulo Freire: His Life and Work. New York: SUNY Press.

Gadotti, M. (2001). Um Legado de Esperança. São Paulo: Cortez.

Gerhardt, H. P. (1996). Uma voz europeia: Arqueologia de um pensamento. M. Gadotti (org.), Paulo Freire: Uma biobibliografia (pp. 149-170), São Paulo: Cortez Editora.

Gonçalves, L. G. (2010). A noção de corpo(s) consciente(s) na obra de Paulo Freire. In A. V. S. Diniz (org.), A aprendizagem ao longo da vida e a educação de jovens e adultos: possibilidade e contribuições ao debate. João Pessoa: UFPB.

Holbrook, J. (2013). Catholic Student Movements in Latin America: Cuba and Brazil, 1920s to 1960s (Tesis inédita de doctorado), Florida International University, Miami.

Horton, M., \& Freire, P. (1990). We make the road by walking. Conversations on education and social change. Philadelphia: Temple University Press.

Jardilino, J. R. L. (2008). Paulo Freire, Filósofo, Pedagogia e Cientista Social: Singularidade e a Universalidade do seu Pensamento. Revista Historia de la Educación Latinoamericana, 10, pp. 41-56.

Jorge, J. S. (1979). A ideologia de Paulo Freire. São Paulo: Loyola. 
Kirylo, J. D., \& Boyd, D. (2017). Paulo Freire His Faith, Spirituality, and Theology. Rotterdam: Sense Publishers. doi: https://doi.org/10.1007/978-94-6351-056-1

Klenk, H. (2014). Emmanuel Mounier e Paulo Freire: um estudo sobre a influência epistemológica do personalismo sobre o pensamento pedagógico de Paulo Freire. Revista HISTEDBR On-line, 58, pp. 244-256. doi: https://doi.org/10.20396/rho.v14i58.8640391

Krees, T., \& Lake, R. (2013). Freire and Marx in Dialogue. In R. Lake, T. Krees (eds.), Paulo Freire's Intellectual Roots. Toward Historicity in Praxis (pp. 29-52). New York: Bloomsbury.

Lacroix, J. (1981). Le Personnalisme. Sources, fondements, actualité. Lyon: Chronique sociale.

Lake, R., \& Dagostino, V. (2013). Converging self/other awareness: Erich Fromm and Paulo Freire on transcending the fear of freedom. In R. Lake, T. Krees (eds.), Paulo Freire's Intellectual Roots. Toward Historicity in Praxis (pp. 101-126). New York: Bloomsbury.

Leach, T. (1982). Paulo Freire: Dialogue, politics and relevance. International Journal of Lifelong Education, 1(3), pp. 185-201. doi: https://doi.org/10.1080/0260137820010302

Leopando, I. (2017). A Pedagogy of Faith: The Theological Vision of Paulo Freire. London-New York: Bloomsbury. doi: https://doi.org/10.5040/9781474203883

Lorenzon, A. (1996). Atualidade do pensamento de Emmanuel Mounier. Ijuí: Universidade Regional do Noroeste do Estado do Rio Grande do Sul.

Mafra, J. F., \& Camacho, C. M. P. (2017). Paulo Freire e o materialismo histórico: um estudo de «extensão ou comunicação?». Revista Pedagógica, 19(41), pp. 118-136. doi: https://doi.org/10.22196/rp.v19i41.3800

Malagón Plata, L. (2010). Ideas pedagógicas de Paulo Freire:pedagogía, política y sociedad. Guatemala: Editorial Magisterio.

Manacorda, M. A. (2008). Marx e l'educazione. Roma: Armando.

Maritain, J. (1936). Humanisme intégral. Problèmes temporels et spirituels d'une nouvelle chrétienté. Paris: Aubier.

Marx, K. (1961). Economic and Philosophic Manuscript of 1844. Moscow: Foreign Languages Publishing House.

Marx, K. (1971). Contribution to the Critique of Political Economy. London: Lawrence \& Wishart.

Marx, K. (1975). On the Jewish Question. In Marx and Engels Collected Works, vol. 3 (pp. 146-174). Moscow: Progress Publishers.

Marx, K. (1978). Theses on Feuerbach. In R. Tucker (ed.), The Marx-Engels Reader (pp. 143-145). New York: W.W. Norton and Company.

Marx, K., \& Engels, F. (1947). German ideology. New York: International Publishers.

Mata da, V. A. (2016). Educação e liberdade: a pedagogia histórico crítica e a emancipação humana. Revista Histedbr On-line, 66(15), pp. 211-221. doi: https://doi.org/10.20396/rho.v15i66.8643711

Mayo, P. (1999). Gramsci, Freire and Adult Education: Possibilities for Transformative. New York: Zed Books.

Mayo, P. (2004). Liberating praxis: Paulo Freire's legacy for radical education and politics. Rotterdam: Sense Publishers.

McLaren, P., \& Farahmandpur, A. (2002). Freire, Marx, and the new imperialism: Toward a revolutionary praxis. In J. Slater, S. Fain, C. Rossatto (eds.). The Freirean Legacy: Educating for Social Justice (pp. 36-56). New York: Peter Lang.

Mendonça de, N. J. A. (2008). Pedagogia da Humanização - A pedagogia bumanista de Paulo Freire. São Paulo: Paulus.

Morrow, R.A., \& Torres, C.A. (2002). Reading Freire and Habermas: Critical pedagogy and transformative social change. New York: Teachers College Press.

Mounier, E. (1935). Révolution personnaliste et communautaire. Paris: F. Aubier.

Mounier, E. (1936). Manifeste au service du personnalisme communautaire. Paris: Aubier.

Mounier, E. (1946). Traité $d u$ caractère, Paris: Seuil.

Mounier, E. (1949). Le personnalisme. Paris: PUF.

Paiva, V. P. (1980). Paulo Freire e o nacionalismo-desenvolvimentista. Rio de Janeiro: Civilização Brasileira.

Preiswerk, M. (1995). Educación Populary Teología de la Liberación. Buenos Aires: CELADEC.

Rivera, R. (2004). A Study of Liberation Discourse: The Semantics of Opposition in Freire and Gutierrez. New York: Peter Lang.

Roberts, P. (1998). Knowledge, dialogue and humanization: The moral philosophy of Paulo Freire. Journal of Educational Thought, 32(2), 1998, pp. 95-117. 
Roberts, P. (2000). Education, Literacy and Humanization. Exploring the Work of Paulo Freire. Westport: Bergin \& Garvey.

Ruedell, A. (1985). Lições politicas para a América Latina. Canoas: La Salle.

Sánchez Vázquez, A. (1967a). Prólogo. In K. Kosík, Dialéctica de lo concreto. Estudio sobre los problemas del hombre y el mundo (pp. 9-19). Ciudad de México, Grijalbo.

Sánchez Vázquez, A. (1967b). Filosofía de la praxis. Ciudad de México: Grijalbo.

Schaff, A. (1970). Marxism and the Human Individual. New York: McGraw-Hill.

Schugurensky, D. (2011). Paulo Freire. London: Bloomsbury.

Scocuglia, A.C. (1999). A História das ideias de Paulo Freire e a atual crise de paradigmas. João Pessoa: Ed. Universitária - UFPB.

Secci, C. (2017). Freire filosofo e traduttore di approcci filosofici. In P. Ellerani, D. Ria (a cura di), Paulo Freire pedagogista di comunità: libertà e democrazia in divenire (pp. 239-252). Lecce: Università del Salento.

Skalinski Junior, O. (2015). Alceu Amoroso Lima e a renovação da pedagogia católica no Brasil (1928-1945): uma proposta de espirito católico e corpo secular. Curitiba: CRV. doi: https://doi.org/10.24824/978854440359.4

Taylor, P. (1993). The Texts of Paulo Freire. Buckingham: Open University Press.

Torres, C. A. (2017). First Freire. Early Writings in Social Justice Education. New York: Teachers College University. 